\title{
Effect of teaching poultry production on choice of career by Agricultural Science students in secondary schools in the Southern Senatorial Zone, Adamawa State, Nigeria
}

\author{
Gwarkila Kaduna ${ }^{1}$, Nuhu Richard ${ }^{2^{*}}$ and Hamira Yoila ${ }^{2}$ \\ ${ }^{1}$ Faculty of Science and Science Education, Adamawa state university, Mubi, Nigeria. \\ ${ }^{2}$ Physics Department, Adamawa State University, Mubi, Adamawa State University, Nigeria. \\ *Corresponding author. Email: nurichie2000@gmail.com; Tel: +2348036237471.
}

Copyright @ 2019 Kaduna et al. This article remains permanently open access under the terms of the Creative Commons Attribution License 4.0, which permits unrestricted use, distribution, and reproduction in any medium, provided the original work is properly cited.

Received 29th November, 2018; Accepted 18th February, 2019

\begin{abstract}
The study was carried out to investigate the effect of teaching poultry production on choice of career by Agricultural Science students in secondary schools in Southern Senatorial Zone, Adamawa State, Nigeria. The study used survey research design. Six hundred and forty-four (644) respondents out of 18,556 were selected from 30 schools that were purposely selected out of 175 in Southern Senatorial zones, using proportional random sampling techniques. Two research questions and two null hypotheses were formulated to guide the study. The instrument used for data collection was the questionnaire. Pearson Product Moment Correlation (PPMC) statistics was used to test all the two null hypotheses at 0.05 level of significance. All the two null hypotheses were rejected because for each of the null hypothesis the $(p)$ value was less than 0.05 level of significance. Among the findings of the study were: The review of the curriculum of agricultural science had direct effect on poultry production in secondary schools because the use of practical methods of teaching poultry production in secondary schools enhanced the subject learning process. Also, the ideas from extension workers and specialist in poultry production made significant effect on poultry production. The distribution of teachers according to their sex indicated that 27 of the respondents representing $96.45 \%$ were male, while one of the respondents that is $3.5 \%$ was a female. The distribution of poultry attendants according to sex showed that 25 of the respondents representing $89.29 \%$ were male, while 3 of the respondents, that is $10.71 \%$ were female. The study considered two research questions and two null hypotheses.
\end{abstract}

Keywords: Choice of career, poultry production, secondary schools, Southern Senatorial Zone.

\section{INTRODUCTION}

Agricultural science students need a good understanding of poultry production and management techniques in choosing it as a career. Poultry production requires well trained and experienced teachers. These teachers are saddled with the responsibility of imparting knowledge to students who will like to take up poultry production as career. They also help in training farmers who have little or no knowledge in poultry management. The effect of this is that, most incompetent people are employed or take up poultry business without undergoing training in poultry production.
Akinsorotan et al. (2007) stated that in the developing countries of the world where there is inadequate career guidance, the young ones tend to choose the career line of their parents most especially fathers' occupation. They further stated that, the educational system of the country stipulated that secondary school to be for children between 12 and 18 years. This is the time when they can be tutored and guided towards choosing a career.

They also stated that one of the major problems facing Nigeria is unemployment of youths due to unfavorable disposition to agriculture as a career and all efforts by 
Government and Non-Governmental Agencies to encourage youths to choose agriculture production as a career have not been effective. Hence, for the young generation participation on agriculture production there should be a positive perception of agriculture production as a progressive and reliable career in order to reverse the drifting of youths towards other professions.

Ogbazi (1988) observed that poultry production in recent times has become an enterprise of concern to individual families and schools. Based on his observation, poultry production is relatively less capital intensive compared to other kinds of livestock production. This makes it possible for most secondary schools to establish poultry in their school farms. He further pointed out that teachers of agriculture should help agriculture students and other people who are interested in establishing poultry farms in schools or in their homes. Onu (2005) maintained that livestock farms in secondary schools when properly established will equipped the students with relevant skills.

Agriculture teachers have the responsibility of educating agricultural science students as prospective farmers in the different methods of producing and processing agricultural products. In order to be able to perform this function, the teachers need to be knowledgeable of the most effective methods of teaching vocational or skill-oriented subject (Ogbazi, 1988).

Agidi (2014) stated that, journey back to the history of agriculture in Nigeria, there is now a trend that is bringing a great concern to the future of agriculture and food production. It is necessary to educate and make the young generation to be conversant with agricultural farming in order to encourage them to contribute to food production and distribution in the country. Mayer and Onaze (1996) in Akinsorotan et al. (2007) stressed that students who were also in the post primary education stage were taught in the classroom about modern methods of agricultural farming with practical training on the school farm. The National Policy on Education (2004), defined Vocational and Technical Education "as the Education designed to prepare individuals to acquire practical skills, basic scientific knowledge and attitude acquired as a craftsman and technician of sub professional level".

\section{Statement of the problem}

Government is no longer equipping poultry farms in public secondary schools to make today's modern poultry farming efficient and effective. Institution poultry farms such as secondary schools enhance teaching and learning process and motivate the learners to choose poultry production as a future career. The students should be acquainted with all the skills required in poultry production and be able to apply such knowledge effectively after completion. In the five educational zones in Adamawa State, the researcher observed that, most students performed poorly in the West African School Certificate
Examination Practical. It was further observed by the researcher that secondary school students were not adequately exposed to poultry production practical due to poor teaching methods, unqualified agricultural science teachers and specialists in poultry production, inadequate modern poultry equipment and facilities among others. This poor state of affairs contributed to unemployment of youths in Adamawa State.

Base on this, the study attempts to determine the effect of teaching poultry production and choice of carrier by agricultural science students in secondary schools in Adamawa State.

\section{Research questions}

The study seeks to answer the following research questions:

1. What are the effects of teaching Agricultural Science on poultry production in secondary schools in Adamawa state?

2. What are the methods used in teaching Agricultural Science in poultry production in secondary schools in Adamawa state?

\section{Hypotheses}

$\mathrm{H}_{01:}$ There is no significant relationship between teaching Agricultural Science and poultry production in secondary schools in Adamawa State.

$\mathrm{H}_{\mathrm{O} 2}$ : There is no significant relationship between methods used in teaching poultry production and student's choice of poultry production as a career in secondary schools in Adamawa State.

\section{MATERIALS AND METHODS}

Proportion sampling techniques was used in the selection of sample size from the target population. This technique was chosen because the number of schools and students in each educational zone were not the same. The instrument used for data collection was a structured questionnaire. The mean, standard deviation and standard error were used to find the level of opinion of respondents to research questions. Data were described using descriptive statistics such as frequency counts and percentages. Pearson Product Moment Correlation (PPMC) of significance was used during the analysis. The study sampled 28 principals, 28 agricultural teachers, 28 poultry attendants and 560 agricultural science students as the respondents.

\section{Reliability indices}

In order to determine the reliability co-efficiency by 
Table 1. Pearson Product Moment Correlation (PPMC) statistic on the difference between teaching Agricultural Science and Poultry production in Adamawa state.

\begin{tabular}{lllllll}
\hline Variables & N & Mean & SD & Correlation index r & Df & Sig (P) \\
\hline Teaching Agricultural Science & 630 & 14.84 & 2.68 & \multirow{2}{*}{$0.644^{* *}$} & \multirow{2}{*}{628} & \multirow{2}{*}{0.000} \\
Poultry production & 630 & 64.17 & 6.70 & & \\
\hline
\end{tabular}

${ }^{* *}$ Correlation is significant at the 0.0 .01 level $(2$-tailed $)$, sig $(p<0.01)$.

Table 2. Pearson Product Moment Correlation (PPMC) statistics on the difference between methods used in teaching poultry production and student's choice of poultry production as a career on secondary school.

\begin{tabular}{lcccccc}
\hline Variables & N & Mean & SD & $\begin{array}{c}\text { Correlation } \\
\text { index r }\end{array}$ & df & Sig (P) \\
\hline $\begin{array}{l}\text { Methods used in teaching poultry } \\
\text { production and }\end{array}$ & 630 & 16.78 & 1.93 & & & \\
$\begin{array}{l}\text { Student choice of poultry production } \\
\begin{array}{l}\text { as a career in secondary school in } \\
\text { Adamawa state }\end{array}\end{array}$ & 630 & 16.69 & 2.27 & $0.482^{\star *}$ & 628 & 0.000 \\
\hline
\end{tabular}

${ }^{\star *}$ Correlation is significant $t$ the 0.01 level of $(2$-tailed $) \operatorname{sig}(p<0.01)$.

Guttman option of split-half and Brown reliability coefficient were used. Consequently, reliability co-efficient of alpha level of 0.840 and standard alpha level of 0.910 were obtained. This reliability co-efficient were considered adequate for internal consistencies of the instrument. This was a confirmation of test of reliability which Spiegel and Steven (1999) said that an instrument to be considered reliable if it lies between 0 and 1 that the closer the calculated reliability co-efficient is to zero, the less reliability of the instrument.

\section{RESULTS}

$\mathrm{H}_{01}$ : There is no significant difference between teaching agricultural science and poultry production in Adamawa State.

Table 1 showed that there was significant relationship between teaching Agricultural Science and poultry production. This is because the calculated $(P)$ value of 0.000 was less than the 0.01 level of tolerance with a correlation index value of 0.644 . Therefore, the null hypothesis which stated that there is no significant relationship between poultry production and teaching Agricultural Science was rejected.

$\mathrm{HO}_{2}$ : There is no significant relationship between methods used in teaching poultry production and student's choice of poultry production as a career in secondary schools in Adamawa state.

Table 2 showed that there was significant relationship between the methods used in teaching poultry production and student choice of poultry production as a career. This is because the calculated significant $(P)$ value of 0.000 was less than 0.01 level of tolerance with a correlation index value of 0.482 . Therefore, the null hypothesis which stated that there is no significant relationship between methods used in teaching poultry production and student's choice of poultry production as a career in secondary schools was rejected.

The distribution of students according to their sex showed that 399 of the respondents representing $72.5 \%$ were male, while 161 representing $27.5 \%$ were female. The distribution of principals according to their sex revealed that 25 of the respondents, that is $88.5 \%$ were males, while 3 of the respondents representing $11.5 \%$ were females. The distribution of teachers according to their sex indicated that 27 of the respondents representing $96.45 \%$ were male, while 1 of the respondents, that is $3.5 \%$ was a female. The distribution of poultry attendants according to sex showed that 25 of the respondents representing $89.29 \%$ were male, while 3 of the respondents, that is $10.71 \%$ were female.

\section{DISCUSSION}

Null hypothesis $\left(\mathrm{H}_{01}\right)$ showed that there was significant relationship between teaching Agricultural Science and poultry production. Poultry production is a component of Agricultural Science. Ogieva (2003) define Agricultural Science as the production of crops, rearing of animals and general soil management. From the foregoing, it can be said that the level of poultry production determines by the emphasis on the Agricultural Science. This explained why the respondent had highest mean response of 3.51 on the effect of teaching Agricultural Science on poultry production. 
Null Hypothesis $\left(\mathrm{H}_{0}\right)$ also showed that there was significant relationship between methods used in teaching poultry production and student's choice of poultry production as a carrier in secondary schools. The respondent's highest mean responses of 3.49 indicate that use of practical method of teaching poultry production in secondary school enhanced the subject learning process. Also, the curriculum of poultry production should include ideas from extension workers and specialists in poultry production. The implication from the foregoing was that the teaching method adopted significantly influenced the student choice of poultry production as a carrier. The use of practical method was therefore the best method of teaching Agricultural Science in order to enhance student's choice of carrier in poultry production (Ogbazi 1988)

\section{Conclusion and recommendation}

Based on the findings of this research, it can be concluded that the teaching of poultry production to the Agricultural Science students contributed to the choice of poultry production as career by the students in Secondary Schools in Adamawa State. There was increase in the level of awareness on the importance of poultry production, as well as government support for agricultural teachers. Hence, it is recommended that Governments (State, Local) should encourage poultry production by providing special incentives and remuneration for Agricultural Science teachers and specialists in poultry production. The use of practical teaching methods should be encouraged in the teaching of poultry production to the students in the secondary schools in Adamawa State.

\section{CONFLICT OF INTEREST}

The authors declare that they have no conflict of interest.

\section{REFERENCES}

Agidi, G. A. (2014). Issues, paper educational content and delivery system related to moral youth programmes. Ministry of Agriculture, Livestock Department and Marketing, Kenya.

Akinsorotan, O. A., Adesiji, G. B., Ogunlade, I., \& Opabo, A. O. (2007). Effect of school agricultural programme of Oyo State on career choice of school students in Ibadan South West Local Government Area of Oyo State. Nigeria. Agricultural Journal, 2(6), 667-671.

Mayer, K. B., \& Onazi, G. O. (1996). Agricultural Education in western Nigeria school. University press limited (UPL) Ibadan, p. 32.

National Policy on Education (2004). Fourth Edition, Section 4 and 5, NERDC Press Yaba Lagos, Nigeria. Pp. 17-25.

Ogbazi, N. J. (1988). Professional and technical competencies needed by agriculture teachers for effective teaching of poultry production in secondary school. Samaru Journal of Agricultural Education, 87(17), 2-7.

Ogieva, E. (1998). Comprehensive Agricultural Science for Schools. A Johnson Publishers Ltd.

Onu, F. M. (2005). Constraint militating against the establishment of livestock farms in secondary schools in South Eastern Nigeria. Journal of Education for Professional Growth. A publication of the Association of Educationists for professional growth in Nigeria, Enugu State University of Science and Technology, 1(1), 215-223. 